\title{
PGPR BACTERIA - PROMISING OBJECTS TO CREATE BIOFERTILIZERS OF COMPLEX ACTION
}

\author{
Abdykadyrova A.B. ${ }^{1}$, Aipova R. ${ }^{1}$, Raisov B.O. ${ }^{2}$, Kurmanbaev A.A. ${ }^{1}$ \\ ${ }^{1}$ National Center for Biotechnology \\ 13/5, Korgalzhyn road, Nur-Sultan, 010000, Kazakhstan \\ ${ }^{2}$ M.Auezov South Kazakhstan state University \\ 5, Taukekhan avenue, Shymkent, 160012, Kazakhstan \\ Abd.aizhan@gmail.com
}

\begin{abstract}
ABSRACT
The review summarizes literature data and the results of the authors own research on the agronomically useful group of soil microorganisms stimulating plant growth (plant-growth-promoting rhizobacteria - PGPR bacteria). PGPRs have great potential for plant growth promoting as they control pest and disease and have been considered important in sustainable agriculture. PGPR includes a promising group of bacteria that live on the surface and inside the roots of agricultural plants. They possess a number of positive properties such as fixation of molecular nitrogen of the atmosphere, decomposition of harmful chemical compounds, synthesis of substances of a hormonal nature, are able to transform difficult phosphorus soil compounds, and also prevent or reduce the growth of phytopathogens due to the ability to synthesize substances with bactericidal and fungicidal effects, as well as competition for ions iron, without which the growth of phytopathogens is difficult. In addition, PGPR bacteria provide plant resistance to adverse environmental factors: heavy metal pollution of the soil, soil salinization, and drought. Under stress caused by heavy metal contamination of the soil, PGPR bacteria enhance plant survival. Data are presented showing the prospects of using these microorganisms in the development of technologies of ecological farming in order to increase plant productivity, biocontrol over the development of plant diseases, reduce the chemical load on the soil, increase its fertility.

Keywords: rhizobacteria, inoculation, phytohormones, growth-stimulating activity, nitrogen fixation, agricultural crops, yield.
\end{abstract}

\section{INTRODUCTION}

Environmentally oriented management of agro-ecosystems with depleted biodiversity and significant human energy costs is aimed at enhancing the biological potential of their natural components. According to modern ideas, the plant is the regulator of the microbial community with which it is in spatial and functional unity [1]. Microbial components contribute to increasing the environmental self-sufficiency of a plant organism, increasing its resistance to stresses; make a favorable impact on the productivity of agricultural crops and fertility of the soil $[2,3]$.

Necessary condition of ecological agriculture development is the creation of methods and technologies of formation, maintaining and effective functioning, the highintegrated microbial and vegetation systems combining the useful properties of both plants, and microorganisms. From this point of view creation in the soil of the multicomponent systems reproducing optimum natural agrophytocenosis and providing 
high stability of agriculture is perspective [4]. The researches directed to creation of highly productive agrophytocenosis by selection of the fissile complementary partners (plant + microorganisms) are relevant for crop production.

Soil microflora - an obligatory component of any agrophytocenosis where between plants and microorganisms molecular interactions which essence consists in the exchange of metabolites and their transformation are carried out [5]. Microorganisms promote formation in a rhizospheric zone of nutrients fund available to a plant and the physiologically fissile connections regulating metabolism and relationship between partners [6]. Also, antibiotic substances oppressing development of phytopathogens are a part of the rhizospheric microorganisms' metabolites [7]. It is apparent that the range of interaction mechanisms of an agrophytocenosis partners is under the influence of various environmental factors and can be carried out efficiently under optimal conditions.

Plant Growth-Promoting Rhizobacteria (PGPR). The microorganisms which are in association with a plant can be divided on spatial location into the ectophytes living on surfaces of plants, and the endophytes inhabiting internal vegetable fabrics. In turn, ectophytes can be: phyllospheric, being on leaves; rhizospheric, living in a radical zone of plants; rhizoplanic, inhabiting immediately a root surface. Endophytic microorganisms can also live in various bodies and fabrics of a vegetable organism and to move on intercellular duct and vials of plants. It is known that the majority of the plant-associated bacteria can have growth-stimulatory properties [8]. In the last 40 years for the microorganisms which are stimulating body height of plants, the concept PGPR (Plant Growth Promoting Rhizobacteria) is used. For the first time this term was introduced by J. Kloepper with the coauthor in the late seventies [9]. However, now it is expedient to use the concept PGPB (Plant Growth Promoting Bacteria) which unites rhizospheric and endophytic bacteria in one growth-stimulatory of bacteria group, dividing them according to spatial location into PGPR (Plant Growth Promoting Rhizobacteria) and PGPE (Plant Growth Promoting Endophytes). Now quite extensive knowledge of an ecological role of PGPR is accumulated. It is known that strengthening of plants' body height happens for the account: suppression by these bacteria of the diseases caused by vegetable pathogens [10]; competition to pathogenic microorganisms for colonization of roots [11]; transfer of insoluble phosphates and oxides of iron to the forms acquired by plants [12]; products physiologically the active materials, such as auxins [13], gibberellin [14], cytokinin [15]; decrease in level of ethylene in roots [16]; activation of system stability of plants [17]. It is also established that PGPR facilitates osmotic stress transferring by plants. [18]. To PGPR belong microorganisms of the genera: Bacillus sp., Paenibacillus sp., Klebsiella sp., Pseudomonas sp., Enterobacter sp., Azospirillum sp., etc. [19]. On the figure 1 summarizes the beneficial effects of PGPR bacteria. 


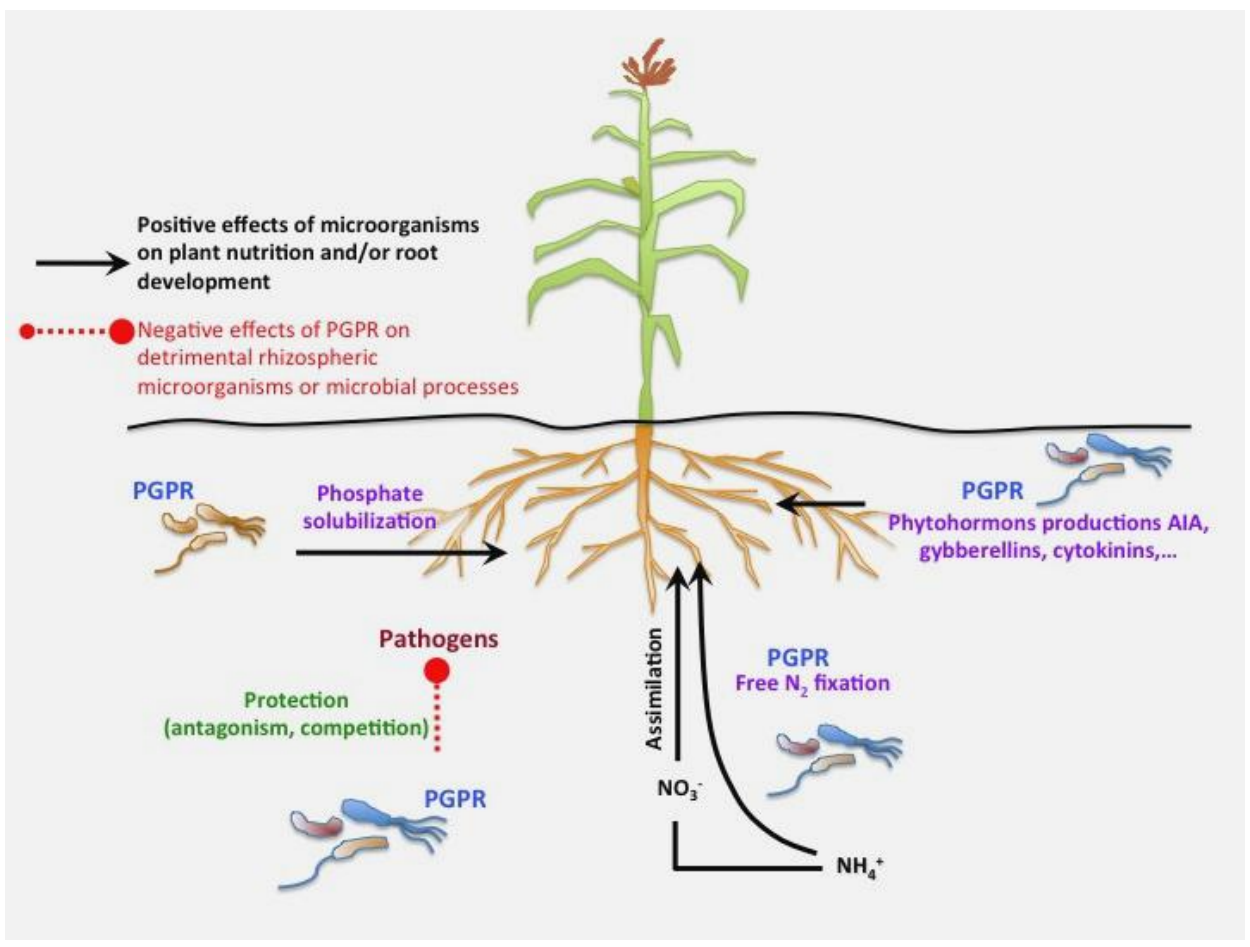

Fig. 1. Plant-beneficial effects of plant growth promoting rhizobacteria (PGPR), [20]

On the basis of functionality. Increase in productivity of crops substantially depends on their security with elements of a mineral delivery, first of all - nitrogen. A source of environmentally friendly biological nitrogen in the soil are the microorganisms capable to fix molecular nitrogen of the atmosphere [21].

Using in practice of agriculture the biological drugs created on the basis of PGPR bacteria is one of the processing methods promoting increase in a harvest of cultural plants and accumulation in the soil of biological nitrogen [22]. Also two - three - and the four-component microbic medicines including legume bacteria, rhizobacteria, mycorrhizal fungi and biologically the active materials are perspective.

PGPR bacteria are characterized by a row positive (direct and mediated) effects of action on plants among which are defining ability to fixing of molecular nitrogen of the atmosphere, synthesis of substances of the hormonal nature, namely, auxin, gibberell ic, cytokinin, vitamins, substances of the antibiotic and antifungal nature, ability to mobilization of almost insoluble phosphates of the soil and decomposition of harmful chemical combinations [23].

The microorganisms which are in association with a plant are capable to synthesize the substances of the phytohormonal nature necessary for them both for own development, and for establishment of communications with plants and other soil microorganisms. Formation of hormones - one of important properties the rhizospheric, the epiphytal and the symbiotic bacteria stimulating body height of plants. Formation of gibberellin is peculiar to epiphytal and rhizospheric bacteria representatives of the genera Azotobacter, Azospirillum, Pseudomonas, Bacillus, Flavobacterium, Clostridium, Agrobacterium [24].

Cytokinins are formed by the rhizobacteria belonging to the genera Azotobacter, Azospirillum, Pseudomonas, Bacillus, etc. [25]. Microorganisms are capable to synthesize kinetin, zeatin, isopentenyladenine and some other derivates. It is considered that in plants a cytokinin can contain both in the free look and in the form of ribosides or glucosides, which biological activity is reduced or is absent. By accession of carbohydrates to a phytohormone molecule in a cage concentration of the fissile 
cytokinin is regulated [26]. Similar zeatinribosidic complexes can also form rhizospheric bacteria of the sorts Azotobacter and Bacillus.

In the nature microorganisms are in communities, therefore, biosynthesis of the molecules, which are stimulating body height and development of both plants, and microorganisms, amplifies in their interaction. It is promoted also by the fact that predecessors of phytohormones, for example, a tryptophan, are allocated in a rhizospheric zone with root exudates of plants [27]. The metabolites of plants excreted to the rhizospheric soil contain the various nutrients attracting microorganisms [28].

The effect of PGPR bacteria on plants. PGPR strains of bacteria stimulate body height and development of plants not only due to formation biologically of the active materials, but also due to ability to a nitrogen-fixation, improvement of a water and mineral delivery of plants, prevention or decrease of body height of phytopathogens in response to an opportunity to synthesize substances of bactericidal and fungicide action [29].

The stimulating action the rhizospheric microorganisms on body height of plants is bound to activation of an associative and a symbiotic nitrogen-fixation and physiological processes in plants, improvement mineral including nitric supply, increase in accumulation of biological nitrogen in them.

The ability to transform the inaccessible compounds of phosphorus which are contained in the soil also belongs to a complex of the positive effects rendered by PGPR bacteria on a plant. The microorganisms dissolving phosphates contribute to body height and the development of plants. It is known that rhizospheric microorganisms of the sorts Bacillus and Enterobacter are capable to mobilize almost insoluble phosphates of the soil owing to functioning of bacterial phosphatases. Acceleration of body height of plants and an increase in absorption of phosphorus - not the single mechanisms of positive influence of these microorganisms on plants. Microbiological mediated dissolution of phosphates by a release of organic acids often is combined with formation of other metabolites which participate in the biocontrol phytopathogen which are transmitted through the soil [30].

The ability of microorganisms to synthesize the substances possessing antibacterial and fungitoxic action belongs to the mediated effects of influence of PGPR-bacteria on plants. In the conditions of in vitro, it is shown that phosphorus mobilizing microorganisms synthesize and release the metabolites suppressing phytopathogens, namely, siderophore, phytohormones, lytic enzymes. As a result of the effect of these substances on a pathogenic microflora (fungi, bacteria) rhizobacterium carry out biocontrol of infection of plants [31]. On the figure 2 shows plant growth stimulation.

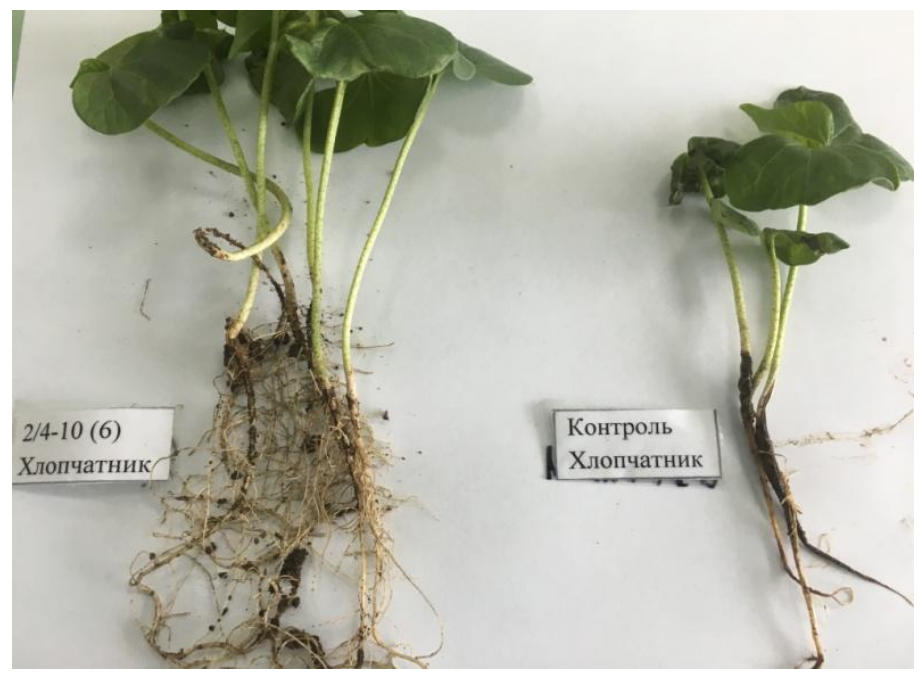

Fig. 2. The effect of PGPR on plant root formation (author fhoto) 
Diseases of plants cause an enormous loss for millions of dollars annually, reducing the harvest of plants and their quality due to accumulation of mycotoxins in grain. The infinite variety and complexity of many diseases of the plants caused by fungi leads to production of the corresponding number of fungicides, however, are pathogenic plants over time develop resistance to particular fungicides.

Alternative to fungicides are allelopathic substances of microorganisms.

PGPR besides antibiotics produce the substances suppressing body height of phytopathogens. Siderophore, flying biocides, the lytic and detoxicating enzymes are carrying to them. These substances call allelopathic substances of microbic origin.

Lytic enzymes destroy organic matters, including chitin of cellular walls of fungi (a chitinase, $\beta$-1.3-glucanase, proteases, etc.), detoxifying ferments prevent the destructions caused by toxins of pathogens. Volatile compounds, such as Hydrogenium Cyanidums, ethylene, ammonium, the ethylene carboxylic acid, trimethylamine, benzaldehyde, etc. suppress body height of mushroom pathogens. The perspective direction is elimination of autoinduction quorum of sensing at pathogens. It can be the enzymes lysing alarm molecules or their inactive chemical analogues.

Role of PGPR in soil fertility. Bacteria PGPR, realizing these or those mechanisms of management of phytopathogens widely use in field conditions. These are representatives of the genera Bacillus, Pseudomonas, Rhizobium, Azospirillum and Burkholderia [32].

Selection of siderophore of PGPR in the conditions of limitation of iron reserves in the soil can promote body height of plants, directly delivering iron for utilization of plants and deleting iron from a surrounding medium for body height of phytopathogens, thereby reducing their competitiveness [33].

Strains of PGPR cause enzymatic degradation or deformation of components of a cellular wall of fungal pathogens enzymes of a chitinase, $\beta$-1.3-glucanase, proteases etc, it is one of important mechanisms of biocontrol of pathogenic microorganisms in the soil [34].

Among all strains, there is PGPR Bacillus and Pseudomonas are two most crucial childbirth, widely used in agriculture [35]. Some researchers showed that the bacteria possessing antibiotic action on microorganisms usually show effects of regulation of body height of plants. Bacteria of the sort Pseudomonas develop such antibiotics as phenazines, pyrrolenitrine, cyclic lipopeptide. Bacilli, in turn, produce antibiotics iturin A, mikosubtilin, a bafilomycin. The greatest number of antibiotics among representatives of the sort Bacillus is noted at B. amyloliquefaciens.

Positive effect of bacterization of seeds by PGPR-bacteria depends on a number of factors: activities of the strain of a microorganism, concentration of suspension of cages, quantities biologically the active materials in suspension, processing time of seeds, plant species, a condition of a native microflora at the time of crops, features of the soil, conditions of an agrotechnical complex [36]. The preseeding inoculation of seeds by rhizobacteria of the genera Azotobacter, Azospirillum, Pseudomonas, Bacillus, Flavobacterium, Clostridium, Agrobacterium and others significantly stimulates with viability and germination of seeds, body height and productivity of plants. It is established that there is an introduction to the strains originally isolated from a rhizoplane or rhizosphere of the same plant species much more successfully [37].

It is revealed that PGPR of a bacterium provides resistance of plants to adverse factors of the environment such as pollution of the soil with heavy metals and salinization of soils. 
Mechanism of bacteria detoxicating which are soil polluted by heavy metals can be: (1) an extracellular barrier, (2) fissile transport of ions of metals from a cage, (3) extracellular binding, (4) intracellular binding, (5) restitution of ions of metals. Thereat one strain can possess at the same time several mechanisms of protection [38].

The cellular wall, membrane or the capsule can interfere with hit of ions of heavy metals in a cage. Bacteria can connections of metals by polarized groups of the cellular wall or the capsule [39]. The ability to sorb to a cellular wall and to absorb ions of heavy metals is intracellularly described for many bacteria - representatives of the genera Arthrobacter, Klebsiella, Bacillus, Pseudomonas, Rhizobium, Serratia, Rhodopseudomonas, Lactococcus, and also cyanobacteria, yeast, etc. [40].

In the conditions of the stress caused by pollution of the soil heavy metals as a result of colonization by bacteria of rhizoplane, the survival of bacteria and plants increases [41]. It is known that at an inoculation by bacteria against the background of influence of heavy metals the efficiency of plants comparable with efficiency for lack of heavy metals can be reached [42].

According to a number of authors $[43,44]$, the use of PGPR bacteria reduces the manifestation of negative reactions of plants to biotic and abiotic stresses among which and the important place plays a stress from salinization of the soil. The advantage of use of PGPR bacteria for the plants which are grown up on the salted soils was expressed in increase in body height of roots and escapes, consumption of nutritious elements, hydration, the maintenance of chlorophyll and resistance to diseases [45].

Kohler, etc. [46] showed positive influence on stabilization of soil units of strains of PGPR bacteria of Pseudomonas mendocina. Three isolates of PGPR bacteria $P$. alcaligenes PsA15, Bacillus polymyxa BcP26 and Mycobacterium phlei MbP18 were capable to increase resistance to high temperatures and salt contents, thus, having given them a potential competitive benefit for survival in the droughty and salted soils, such as calci-salt (desert soils, takyry).

D. Ramadoss, etc. [47] studied influence of five salt-resistant PGP bacteria on body height of wheat and found out that the inoculation these salt-resistant strains of bacteria reduced a salt stress $(80,160$ and $320 \mathrm{~mm})$ in wheat sprouts, producing increase in length of roots by $71.7 \%$ in comparison with uninoculated positive control options. In particular, Hallobacillus sp. and B. halodenitrificans showed increase in length of roots more than for $90 \%$ and increase in dry weight by $17.4 \%$ in comparison with uninoculated sprouts of wheat at a salt stress $320 \mathrm{~mm} \mathrm{NaCl}$ that indicates significant decrease of harmful action of $\mathrm{NaCl}$. These results mean that the salt-resistant bacteria isolated from the salted conditions have the potential for improvement of body height of plants at a salt stress via direct and indirect mechanisms and can be used as bioinoculum in such conditions.

The Spanish researchers found out that rhizobial symbiosis of legume bacteria with beans allows to improve osmotic water circulation in a plant the owner in the conditions of salinization. The salt stress causes dehydration of leaves because of an imbalance between the water lost through apertures and absorbed by the water entering through roots. It was revealed that in the conditions of rhizobial symbiosis the condition of sheet water improves and better osmotic water inflows, lower values of concentration of sodium in root fabrics in comparison with not uninoculated plants are also noted. Besides, the decrease in osmotic potential of juice of a xylem and increase in amount of PIP aquaporins favours increasing in current of root osmotic water in the uninoculated plants [48]. Many bacterial biofertilizers have elicitor effects, increasing resistance of plants to adverse factors of the soil environment and phytopathogens. 


\section{CONCLUSION}

Results of the works, which are carried out within the last decade, demonstrate the relevance of various directions of research of the growth-stimulatory of PGPR bacteria, their actions on plants and the soil promoting practical application of these microorganisms in crop production and ecological agriculture. In agricultural production bacterial medicines on a basis of the growth-stimulatory of rhizobacteria were widely used, such as diazofit, rhizoagrin, rhizoenterin, flavorbakterin, diazobakterin, rizobofit, azotobacterin, agrofit, azogran, azorizin and also complex medicines (mikrogumin, polymixobakterin, albobakterin, biorgan) and the medicines of a protective action (fitosporin, chetomic, bitoxibacillin, lepidotsit, bacterodencit, polymixobakterin) created by the Ukrainian scientists (Institute of a microbiology and virology of D.K. Zabolotny NAN of Ukraine, Institute of an agricultural microbiology of UAAN, Institute of agroecology and biotechnology of UAAN) [49].

Thus, competent use of bacterial medicines on a basis the growth-stimulatory of rhizobacteria as element of ecological agriculture in technologies of cultivation of various crops allows to lower significantly chemical load of ecosystems owing to decrease of quantities of the applied mineral fertilizers and chemical means of protection of plants, leads to increase in productivity and improvement of quality of environmentally friendly agricultural products.

\section{Acknowledgements}

This work was supported by the Ministry of Education and Science of the Republic of Kazakhstan (STP BR 05236334, project «Creation and replenishment a collection of microorganism strains with PGPR traits (plant growth promoting rhizobacteria)»).

\section{REFERENCES}

1. Tikhonovich I.A., Provorov N.A. Kooperatsiya rasteniy i mikroorganizmov: novyye podkhody $\mathrm{k}$ konstruirovaniyu ekologicheski ustoychivykh agrosistem [Cooperation between plants and microorganisms: new approaches to the design of environmentally sustainable agricultural systems]. Usp. sovr. biol. - Suc. modern biol., 2007. vol. 127, no. 4, pp. 339-357.

2. Shaposhnikov A.I., Belimov A.A., Kravchenko L.V., Vivanko D.M. Vzaimodeystviye rizosfernykh bakteriy s rasteniyami: Mekhanizmy obrazovaniya i faktory effektivnosti assotsiativnykh simbiozov [Interaction of rhizospheric bacteria with plants: Mechanisms of formation and efficiency factors of associative symbioses]. Sel'skokhozyaystvennaya biologiya - Agricultural biology, 2011, no. 3, pp. 16-22.

3. Ahemad M. Enhancing phytoremediation of chromiumstressed soils through plant-growth-promoting bacteria. J. Genet. Eng. Biotechnol, 2015, vol. 13, pp. 51-58.

. Kruglov YU.V. Mikrobiologicheskiye aspekty plodorodiya pochvy i problemy ustoychivogo zemledeliya [Microbiological aspects of soil fertility and sustainable agriculture]. Plodorodiye - Fertility, 2006, no. 5, pp. 9-12.

5. Tak H.I., Ahmad F., Babalola O. Advances in the application of plant growthpromoting rhizobacteria in phytoremediation of heavy metals. Rev. Environ. Contaminat.Toxicol., 2013, vol. 223, pp. 33-53.

6. Sytnikov D.M. Biotekhnologiya mikroorganizmov azotfiksatorov i perspektivy primeneniya preparatov na ikh osnove [Biotechnology of nitrogen-fixing microorganisms and prospects for the use of drugs based on them]. Biotekhnologiya Biotechnology, 2013, no. 4, pp.16-22. 
7. Compant S., Duffy B., Nowak J. et al. Use of plant growth-promoting bacteria for biocontrol of plant diseases: Principles, mechanisms of action, and future prospects. Appl. and Environ. Microbiol. 2005, no. 9, pp. 4951- 4959.

8. Selivanovskaya S.YU., Latypova V.Z. Mikroorganizmy v krugovorote biogennykh elementov [Microorganisms in the cycle of nutrients]. Kazan': Kazan.un-t, 2014. pp 38.

9. Suslow T.V., Kloepper J.W., Schroth M.N., Burr T.J. Beneficial bacteria enhance plant growth Rhizobacteria J. Calif. Agric., 1979, vol.33. pp. 15-17.

10. Volova T.G. Biologicheskiye udobreniya [Biological fertilizers] Biotekhnologiya - Biotechnology, Novosibirsk, Pressord 2016, pp.159.

11. Golovanov M.T. Rol' tekhnogennykh faktorov v stabilizatsii urozhaya zerna gorokha sortov novogo pokoleniya [The role of technogenic factors in stabilizing the grain crop of peas of new generation varieties]. 2014, no. 1, pp. 3-7.

12. Eid A.R., Awad M.N., Hamouda H.A.Evaluate effectiveness of bio and mineral fertilization on the growth parameters and marketable cut flowers of Matthiolaincana L.. Amer. J. Agric. Environ., 2009, vol. 5, no. 4, pp. 509-518.

13. Vandeputte O., Oden S., Mol A., Vereecke D., Goethals K., El Jaziri M., Prinsen E.Biosynthesis of auxinby the gram-positive phytopathogen Rhodococcus fascians is controlled by compounds specific to infectplant tissues. Appl. Environ. Microbiol., 2005. vol. 71, pp. 1169-1177.

14. Gur'yev G.P. Vliyaniye preparatov kluben'kovykh bakteriy i kompleksnogo mikrobnogo udobreniya (KMU) na simbioticheskuyu azotfiksatsiyu i urozhay gorokha [The effect of nodule bacteria and complex microbial fertilizer (CTO) preparations on symbiotic nitrogen fixation and pea crop]. Nauchno-proizvodstvennyy zhurnal "Zernobobovyye $i$ krupyanyye kul'tury» - Scientific-production journal «Legumes and cereals», 2017, no. 1, pp.15-18.

15. Arkhipova T.N., Veselov S.Y., Melentiev A.I., Martynenko E.V., Kudoyarova G.R. Ability of bacterium Bacillus subtilis to produce cytokinins and to influence the growth and endogenous hormone content of lettuce plants. Plant Soil, 2005, vol. 272, pp. 201-209.

16. Yesaulko A.N., Ageyev V.V., Grechishkina YU.I. Effektivnost' rannevesennikh azotnykh podkormok pshenitsy kul'tur $\mathrm{v}$ razlichnykh pochvennoklimaticheskikh usloviyakh [The effectiveness of early-weighted nitrogen fertilizing wheat crops in various soil and climatic conditions]. Severo-Kavkazskomu Federal'nomu Okrugu: 75-ya nauchno-prakticheskaya konferentsiya «Agrarnaya nauka» [North Caucasus Federal District: 75th Scientific and Practical Conference "Agricultural Science"], 2014. pp. 49-52.

17. Matevosyan, F.S. Vliyaniye kluben'kovykh bakteriy v assotsiatsii s drugimi pochvennymi mikroorganizmami na azotfiksatsiyu rasteniy [The effect of nodule bacteria in association with other soil microorganisms on plant nitrogen fixation]. Biolog.zhurn. Armenii - Biologist. journal of Armenia, 2016, no. 2, pp. 43-47.

18. Han H.S., Lee K.D. Physiological responses of soybean - inoculation of Bradyrhizobium japonicum with PGPR in saline soil conditions. Res. J. Agr. Biol. Sci., 2005. vol. 1, pp. 216-221.

19. Yao A.V., Bochow H., Karimov S., Boturov U., Sanginboy S., Sharipov K. Effect of FZB24 Bacillus subtilis as a biofertilizer on cotton yields in field tests. Arch. Phytopathol. Plant Prot., 2006, vol. 39, pp. 1-6.

20. http://www.ecologiemicrobiennelyon.fr/spip.php?rubrique29\&lang=en

21. Kots' S.YA., Morgun V.V., Patyka V.F Biologicheskaya fiksatsiya azota: bobovo-rizobial'nyy simbioz [Biological nitrogen fixation: bean - rhizobial symbiosis]. M.: Logos, 2017, pp.523 
22. Volkohon V.V. Mikrobiolohichni aspekty optymizatsiyi azotnoho udobrennya silsko hospodarskykh kultur [Microbiological aspects of optimization of nitrogen fertilizer in agricultural crops]. Ahrarna nauka - Agricultural science, 2007, pp.143

23. Tsavkelova Ye.A., Klimova S.YU., Cherdyntsev T.A., Netrusov A.I. Gormony i gormonopodobnyye soyedineniya mikroorganizmov [Hormones and hormone-like compounds of microorganisms]. Prikl. biokhimiya i mikrobiologiya Applied biochemistry and microbiology. 2006, no. 3, pp. 261-268.

24. Tsavkelova Ye.A., Klimova S.YU., Cherdyntsev T.A., Netrusov A.I. Gormony i gormonopodobnyye soyedineniya mikroorganizmov [Hormones and hormone-like compounds of microorganisms]. Prikl. biokhimiya i mikrobiologiya Applied biochemistry and microbiology. 2006, no. 3, pp. 261-268.

25. Arkhipova T.N., Veselov S.YU., Melent'yev A.I., Martynenko Ye.V. Sravneniye deystviya shtammov bakteriy, razlichayushchikhsya po sposobnosti sintezirovat' tsitokininy, na rost i soderzhaniye tsitokininov $\mathrm{v}$ rasteniyakh pshenitsy [Comparison of the effects of bacterial strains that differ in their ability to synthesize cytokinins on the growth and content of cytokinins in plants of bees]. Fiziologiya rasteniy - Plant physiology, 2006, no. 4, pp. 567-74.

26. Ahemada M., Kibret M. Mechanisms and applications of plant growth promoting rhizobacteria: Current perspective. Journal of King Saud University Science, 2014, vol.26, pp.1-20.

27. Kravchenko L.V., Azarova T.S., Makarova N.M., Tikhonovich I.A. Rol' triptofana $\mathrm{v}$ kornevykh ekzometabolitakh dlya fitostimuliruyushchey aktivnosti rizobakteriy [The role of tryptophan in root exometabolites for phytostimulating activity of rhizobacteria]. Mikrobiologiya - Microbiology, 2004, no. 2, pp. 195-198.

28. Stepanyan, T.U. Ispol'zovaniye kluben'kovykh bakteriy $\mathrm{v}$ assotsiatsii $\mathrm{s}$ pochvennymi svobodnozhivushchimi bakteriyami dlya inokulyatsii bobovykh rasteniy [The use of nodule bacteria in association with free-living soil bacteria for inoculation of legumes]. Biolog.zhurn. Armenii - Biologist. journal of Armenia, 2016, no. 3. pp. 1823.

29. Kravchenko L.V., Makarova N.M., Azarova T.S. i dr. Vydeleniye i fenotipicheskaya kharakteristika roststimuliruyushchikh rizobakteriy (PGPR), sochetayushchikh vysokuyu aktivnost' kolonizatsii korney i ingibirovaniya fitopatogennykh gribov [Isolation and phenotypic characterization of growthstimulating rhizobacteria (PGPR), combining high colony activity and inhibition of phytopathogenic fungi]. Mikrobiologiya - Microbiology, 2002, no. 4, pp. 521-525.

30. Vassilev N., Vassileva M., Nikolaeva I. Simultaneous P-solubilizing and biocontrol activity of microorganisms: Potentials and future trends. Appl. Microbiol. and Biotechnol., 2006, vol.71, pp. 137-144.

31. Patsko Ye.V. Perspektivnost' ispol'zovaniya assotsiatsiy azotfiksiruyushchikh mikroorganizmov dlya povysheniya urozhaynosti rasteniy [The prospects of using the association of nitrogen-fixing microorganisms to increase plant productivity]. Byul. Mosk. obshch.isp. prir., 2014, no. 2, pp. 84-86.

32. Saraf M., Pandya U., Thakkar A. Role of allelochemicals in plant growth promoting rhizobacteria for biocontrol of phytopathogens. Microbiological research., 2014, vol. 169, pp.18-29.

33. Tank N, Rajendran N, Patel B, Saraf M. Evaluation and biochemical characterization ofa distinctive pyoverdin from a Pseudomonas isolated from chickpea rhizosphere. Braz J Microbiol, 2012:639-48.

34. Aeron A, Pandey P, Kumar S, Maheshwari DK. Emerging role of plant growth pro-moting rhizobacteria. In: Maheshwari DK, editor. Bacteria in agrobiology: cropecosystem. Berlin/Heidelberg: Springer Verlag, 2011, pp. 1-26. 
35. Jayaprakashvel M, Mathivanan N. Management of plant diseases by microbial metabolites. In: Maheshwari DK, editor. Bacteria in agrobiology: plantnutrient management. Berlin/Heidelberg: Springer-Verlag, 2011, pp. 237-65.

36. Gur'yev, G.P. K voprosu o simbioticheskoy azotfiksatsii v usloviyakh Orlovskoy oblasti [On the issue of symbiotic nitrogen fixation in the conditions of the Oryol region] Zernobobovyye i krupyanyye kul'tury - Legumes and cereals, 2012, no. 2. pp. 66-71.

37. Duran P., Acuca J.J., Jorquera M.A., Azcyn R., Paredes C., Rengel Z., Mora M.L.. Endophytic bacteria from selenium-supplemented wheat plants could be useful for plant-growth promotion, biofortification and Gaeumanno-mycesgraminis biocontrol in wheat production. Biol. Fertil.Soils., 2014, vol.50, pp. 983-990.

38. Choudhury R., Srivastava S. Zinc resistance mechanisms in bacteria. Curr. Sci., 2001, vol. 81, pp. 768-775.

39. Farag M.A., Zhang H., Ryu C.M. Dynamic chemical communication between plants and bacteria through airborne signals: Induced resistance by bacterial volatiles. J. Chem. Ecol., 2013, vol.39, pp.1007-1018.

40. Fokina A.I., Domracheva L.I., Shirokikh I.G., Kondakova L.B., Ogorodnikova S.YU. Mikrobnaya detoksikatsiya tyazhelykh metallov [Microbial detoxification of heavy metals]. Teoreticheskaya i prikladnaya ekologiya - Theoretical and Applied Ecology, 2008, no. 1, pp. 4-10.

41. Pishchik V.N., Vorobyov N.I., Chernyaeva I.I., Timofeeva S.V., Kozhemyakov A.P., Lukin S.M. Experimental and mathematical simulation of plant growth promoting rhizobacteria and plant interaction under cadmium stress. Plant and Soil, 2002, vol. 243, pp. 173-186.

42. Acuca J.J., Jorquera M.A., Barra P.J., Crowley D.E., Mora M.L. Selenobacteria selected from the rhizosphere as a potential tool for Se biofortification of wheat crops. Biol. Fertil. Soils, 2013, vol.49, pp. 175-185.

43. Dodd I.C. Microbial amelioration of crop salinity stress. J. Exp. Bot., 2012, vol. 63, pp. 3415-3428.

44. Yao L., Wu Z., Zheng Y., Kaleem I., Li C. Growth promotion and protection against salt stress by Pseudomonas putida Rs-198 on cotton. Eur. J. Soil Biol., 2010, vol. 46, pp. 49-54.

45. Qurashi A. W., Sabri A.N. Bacterial exopolysaccharide and biofilm formation stimulate chick-pea growth and soil aggregation under salt stress. Braz. J. Microbiol., 2012, vol. 11, pp. 83-91.

46. Kohler J., Caravaca F., Carrasco L., Roldan A. Contribution of Pseudomonas mendocina and Glomus intraradices to aggregates stabilization and promotion of biological fertility in rhizosphere soil of lettuce plants under field conditions. Soil Use Manage, 2006, vol. 22, pp. 298-304.

47. Ramadoss D., Lakkineni V. K., Bose P., Ali S., K. Annapurna Mitigation of salt stress in wheat seedlings by halotolerant bacteria isolated from saline habitats. Springer Plus, 2013, vol. 2, pp. 1-7.

48. Vinicius Ide Franzini, Rosario Azcyn, Juan Manuel Ruiz-Lozano, Ricardo Aroca. Rhizobial symbiosis modifies root hydraulic properties in bean plants under nonstressed and salinity-stressed conditions. Planta, 2019, vol.49, pp. 1207-1215.

49. Morgun V.V., Kots' S.YA, Kirichenko Ye.V. Roststimuliruyushchiye rizobakterii i ikh prakticheskoye primeneniye [Growth-stimulating rhizobacteria and their practical use]. Fiziologiya $i$ biokhimiya kul'tur rasteniy - Physiology and biochemistry of plant crops, 2009, no.3, pp. 41. 


\title{
КЕШЕНДІ ӘСЕР ЕТЕТІН БИОТЫНАЙТҚЫШТАР ӘЗІРЛЕП ШЫҒАРУ ҮШІН ПЕРСПЕКТИВТІ НЫСАНДАР РЕТІНДЕ - РGРR-БАКТЕРИЯЛАР
}

\author{
Әбдіқадірова А.Б. ${ }^{1}$, Аипова Р. ${ }^{1}$,Раисов Б.О. ${ }^{2}$, Курманбаев А.А. ${ }^{1}$ \\ ${ }^{1}$ Ұлттық биотехнология ортальвы \\ Қорвалжын тас жолы, 13/5, Нұр-Султан, 010000, Қазақстан \\ ${ }^{2}$ М.Әуезов атындавы Оңтүстік Қазақсстан Мемлекеттік Университеті \\ Тәуке хан данұвылы,5, Шымкент, 160012, Қазақстан \\ Abd.aizhan@gmail.com
}

\section{ТYЙІН}

Мақалада өсімдіктер өсуін ынталандыратын топырақ микроағзаларының агрономиялық пайдалы тобына қатысты әдебиеттер мен өз зерттеулеріміздің нәтижелері жинақталған (өсімдіктердің өсуіне ықпал ететін ризобактериялар - PGPR бактериялары). PGPR өсімдіктердің өсуін ынталандыратын үлкен қасиетке ие, өйткені олар зиянкестер мен аурулардың алдын алады және тұрақты ауыл шаруашылығы үшін маңызды болып табылады. PGPR құрамындағы бактерияларды ауылшаруашылық өсімдіктерінің тамырларында және бетінде өмір сүретін перспективті тобқа жатқызады. Олар атмосфераның молекулалық азотын бекіту, зиянды химиялық қосылыстардың ыдырауы, гормоналды табиғаттағы заттардың синтезі сияқты бірқатар жағымды қасиеттерге ие, қолжетімсіз топырақ фосфор қосылыстарын түрлендіруге қабілетті, сонымен қатар бактерицидтік және фунгицидтік әсер ететін заттарды синтездейді, фитопатогендердің өсуіне жол бермейді немесе азайтады, фитопатогендердің өсуі онсыз қиын темір иондарына бәсекелестік тудырады. Өсімдіктің өнімділігін арттыру, өсімдік ауруларының пайда болуын биобақылау, топыраққа химиялық жүктемені азайту және оның құнарлылығын арттыру мақсатында осы микроағзалардың экологиялық егіншілік технологияларын дамытуда қолдануды растайтын мәліметтер келтірілген.

Негізгі сөздер: ризобактериялар, егу, фитогормондар, өсуге ықпал ететін белсенділік, азотты бекіту, дақылдар, өнімділік.

\section{PGPR-БАКТЕРИИ - ПЕРСПЕКТИВНЫЕ ОБЪЕКТЫ ДЛЯ СОЗДАНИЯ БИОУДОБРЕНИЙ КОМПЛЕКСНОГО ДЕЙСТВИЯ}

\author{
Әбдіқадірова А.Б. ${ }^{1}$, Аипова Р. ${ }^{1}$, Раисов Б.О. ${ }^{2}$, Курманбаев А.А. ${ }^{1}$ \\ ${ }^{1}$ Национальный иенттр биотехнологии \\ Кургальжинское шоссе, 13/5, Нур-Султан, 010000, Казахстан \\ ${ }^{2}$ Южно-Казахстанский государственный университет имени М. О. Ауэзова \\ пр. Тауке хана, 5, Шымкент, 160012, Казахстан \\ Abd.aizhan@gmail.com
}

\section{АБСТРАКТ}

В обзоре обобщены литературные данные и результаты собственных исследований авторов об агрономически полезной группе почвенных микроорганизмов, стимулирующих рост растений (plant growth-promoting rhizobacteria - PGPR). PGPR имеют большой потенциал для стимулирования 
роста растений, так как они борются с вредителями и болезнями и считаются важными для устойчивого сельского хозяйства. $K$ PGPR относят многообещающую группу бактерий, которые обитают на поверхности и внутри корней сельскохозяйственных растений. Они обладают рядом таких положительных свойств как: фиксация молекулярного азота атмосферы, разложение вредных химических соединений, синтез веществ гормональной природы, способны трансформировать труднодоступные почвенные соединения фосфора, а также предотвращают или уменьшают рост фитопатогенов благодаря возможности синтезировать вещества бактерицидного и фунгицидного действия, а также конкуренцией за ионы железа, без которых рост фитопатогенов затруднен. Кроме того, PGPR бактерии обеспечивают устойчивость растений к неблагоприятным факторам среды: загрязнению почвы тяжелыми металлами, засолению почв и засухе. В условиях стресса, вызванного загрязнением почвы тяжелыми металлами, PGPR бактерии усиливают выживаемость растений. Представлены данные, свидетельствующие о перспективности использования данных микроорганизмов в разработке технологий экологического земледелия с целью повышения продуктивности растений, биоконтроля над развитием заболеваний растений, снижения химической нагрузки на почву, повышения ее плодородия.

Ключевые слова: ризобактерии, инокуляция, фитогормоны, ростстимулирующая активность, азотфиксация, сельскохозяйственные культуры, урожайность. 